\title{
Insulin-mediated activation of activator protein-1 through the mitogen-activated protein kinase pathway stimulates collagenase-1 gene transcription in the MES 13 mesangial cell line
}

\author{
J E Ayala, J N Boustead, S C Chapman, C A Svitek, J K Oeser, R B Robey ${ }^{1}$ and \\ R M O'Brien \\ Department of Molecular Physiology and Biophysics, 761 PRB (MRB II), Vanderbilt University Medical School, Nashville, Tennessee 37232-0615, \\ USA \\ ${ }^{1}$ Section of Nephrology, Department of Medicine, Departments of Physiology and Biophysics, University of Illinois at Chicago College of Medicine and \\ Veterans Affairs Chicago Health Care System, West Side Division, Chicago, Illinois 60612-7315, USA \\ (Requests for offprints should be addressed to R M O'Brien; Email: richard.obrien@vanderbilt.edu)
}

\begin{abstract}
The initial stages of diabetic nephropathy are characterized, in part, by expansion of the mesangial matrix and thickening of the glomerular basement membrane which are caused by increased extracellular matrix (ECM) protein synthesis and reduced degradation, a consequence of decreased matrix metalloproteinase (MMP) activity. These changes have been largely attributed to the effects of hyperglycemia such that the potential contribution of impaired insulin action to alterations in the ECM have not been studied in detail. We have shown here that insulin stimulates collagenase-1 fusion gene transcription in the MES 13 mesangial-derived cell line. Multiple collagenase-1 promoter elements are required for the full stimulatory effect of insulin but the action of insulin appears to be mediated through an activator protein-1 (AP-1) motif. Thus, mutation of this AP-1 motif abolishes insulin-stimulated collagenase fusion gene transcription and, in isolation, this AP-1 motif can mediate a stimulatory effect of insulin on the expression of a heterologous fusion gene. This suggested that the other collagenase-1 promoter elements that are required for the full stimulatory effect of insulin probably bind accessory factors that enhance the effect of insulin mediated through the AP-1 motif. In MES 13 cells, the AP-1 motif is bound by Fra-1, Fra-2, Jun B and Jun D. Stimulation of collagenase-1 fusion gene transcription by insulin requires activation of the mitogen-activated protein kinase (MEK) pathway since inhibition of MEK-1 and -2 blocks this effect. The potential significance of these observations with respect to a role for insulin in the pathophysiology of diabetic glomerulosclerosis is discussed.
\end{abstract}

Journal of Molecular Endocrinology (2004) 33, 263-280

\section{Introduction}

The abundance of extracellular matrix (EGM) protein is determined by the balance of ECM protein synthesis and degradation. The latter is primarily mediated by a family of ECM proteinases, the matrix metalloproteinases (MMPs) (Borden \& Heller 1997, Brinckerhoff \& Matrisian 2002, Visse \& Nagase 2003), whose actions can be modulated through the regulation of their abundance or activity. MMP activity is regulated by the tissue inhibitors of MMPs, which bind covalently to MMPs and prevent both the activation of MMPs and the ability of MMPs to bind substrates (Borden \& Heller 1997, Brinckerhoff \& Matrisian 2002, Visse \& Nagase 2003).

MMP gene expression is regulated by multiple factors (Borden \& Heller 1997, Brinckerhoff \& Matrisian 2002, Visse \& Nagase 2003). The molecular mechanisms that mediate this regulation have received considerable attention primarily because of the potential role of increased MMP 
activity in determining the invasiveness of tumors (Vihinen \& Kahari 2002, Yoon et al. 2003). However, several of the complications associated with both type I and type II diabetes mellitus, including nephropathy (Lenz et al. 2000, Mason \& Wahab 2003), retinopathy (Sivak \& Fini 2002), periodontal disease (Birkedal-Hansen 1993, Reynolds \& Meikle 1997) and various aspects of cardiac disease (Creemers et al. 2001) are also characterized, in part, by alterations in the amount and composition of ECM protein.

The early stages of diabetic nephropathy are characterized by glomerular hypertrophy, expansion of the mesangial matrix and thickening of the glomerular basement membrane, resulting in a reduction of the available filtration surface area and the glomerular filtration rate (Osterby 1996). This expansion of the mesangial matrix and the thickening of the glomerular basement membrane can be attributed to a stimulation of ECM protein synthesis and a decrease in ECM degradation, a secondary consequence of reduced MMP activity (Lenz et al. 2000, Mason \& Wahab 2003). In the streptozotocin rat model of type I diabetes, the expression of genes encoding three prominent MMPs, MMP-1 (collagenase-1; referred to henceforth as collagenase), MMP-2 and MMP-9 is decreased in the glomerulus (Nakamura et al. 1994, McLennan et al. 2002). The decrease in collagenase gene expression is reversed by insulin treatment (Nakamura et al. 1994), but the effect of insulin treatment on MMP-2 and MMP-9 gene expression has not been explored. Moreover, it is unclear whether this change in collagenase expression represents a direct effect of insulin as opposed to an indirect effect mediated through changes in glucose concentration. Nevertheless, a direct stimulatory effect of insulin on collagenase fusion gene transcription has been observed in NIH 3T3 (Medema et al. 1991), CHO.T (Rutter et al. 1995) and HeLa cells (Chapman et al. 1999).

Insulin regulates the transcription of more than 100 genes through cis-acting elements collectively referred to as insulin response sequences or elements (IRSs/IREs) (O'Brien \& Granner 1996, 2004, O'Brien et al. 2001). Unlike cAMP, which regulates gene transcription predominantly through one cis-acting element (Waterman 1994, Montminy 1997, Daniel et al. 1998, Mayr \& Montminy 2001), it is apparent that a single consensus IRS does not exist (O'Brien \& Granner 1996, 2004, O’Brien et al.
2001). Instead, seven distinct classes of IRS have currently been defined, in addition to several IRSs that appear to be unique to individual genes (O'Brien \& Granner 2004). One of these classes of IRS has the sequence T(G/A)TTT(T/G) and mediates the insulin-dependent transcriptional inhibition of several hepatic genes such as those encoding phosphoenolpyruvate carboxykinase (PEPCK), insulin-like growth factor (IGF)-binding protein-1, tyrosine aminotransferase, apolipoprotein CIII and the glucose-6-phosphatase catalytic subunit (O'Brien \& Granner 2004). This class of IRS, designated the PEPCK-like motif (O'Brien et al. 2001, O'Brien \& Granner 2004), binds the transcription factor FKHR (FOXOla), although recent data indicate that this is not the only insulin-regulated factor that can bind this element (Vander Kooi et al. 2003). The other six classes of IRS all mediate stimulatory effects of insulin on gene transcription. They are the activator protein-1 (AP-1) motif, the Spl binding motif, the serum response element, the Ets motif, the thyroid transcription factor-2 motif, and the sterol response element-binding protein motif (O'Brien \& Granner 2004). However, unlike the PEPCK-type IRS that confers a selective effect of insulin (O'Brien \& Granner 2004), the six positive IRSs can mediate the effects of multiple other hormones on gene transcription (Wasylyk et al. 1993, Treisman 1995, Ortiz et al. 1997, Miyazaki et al. 1999, Wisdom 1999, Horton et al. 2002, Samson \& Wong 2002, Shaulian \& Karin 2002, Shimano 2002, Oikawa \& Yamada 2003).

The AP-1 motif mediates the action of insulin on the transcription of the hepatitis $\mathrm{B}$ virus $\mathrm{X}$ gene and the genes encoding collagenase and malic enzyme (Medema et al. 1991, Rutter et al. 1995, Choi et al. 1998, Streeper et al. 1998, Chapman et al. 1999). Heterodimers between members of the Fos (c-Fos; FosB; Fra-1; Fra-2) and Jun (c-Jun; Jun $\mathrm{B}$; Jun D) transcription factor families form a major component of the AP-1 transcription factor complex (Shaulian \& Karin 2002). The mechanism of insulin signaling through the AP-1 motif has not been studied in detail but it appears to involve effects of insulin on both the mass and/or the phosphorylation state of the AP-1 complex (O'Brien \& Granner 1996). However, the mechanism of insulin signaling through AP-1 appears to vary with the cell type studied. For example, the stimulation of Fra-1 gene expression by insulin is 
seen in some (Mamounas et al. 1991, Griffiths et al. 1998) but not all cell types (Mohn et al. 1990). Similarly, the protein kinases JNK-1 and JNK-2, which phosphorylate and activate c-Jun (Shaulian \& Karin 2002), are activated by insulin in rat 1 fibroblasts (Miller et al. 1996) but not in CHO.T cells (Griffiths et al. 1998). In CHO.T cells, activation of the mitogen-activated protein (MAP) kinase pathway is required for insulin signaling through the AP-1 motif, an effect mediated through increased Fra-1 gene transcription and phosphorylation (Hurd et al. 2002) whereas, in adipocytes, this insulin-stimulated induction of Fra-1 gene expression also requires activation of the FRAP/mTOR pathway (Culbert \& Tavare 2002).

In the studies presented here, we have analyzed the effect of insulin on collagenase fusion gene transcription in murine mesangial-derived MES 13 cells. Insulin stimulates collagenase fusion gene transcription in MES 13 cells and this effect requires an AP-1 motif in the collagenase promoter, as it does in HeLa cells (Chapman et al. 1999). However, unlike HeLa cells, a distal collagenase promoter region is necessary for the maximal stimulatory effect of insulin on collagenase fusion gene transcription in MES 13 cells. Moreover, the factors binding the collagenase AP-1 motif in MES 13 and HeLa cells are distinct. Inhibition of MEK-1 and MEK-2 blocks the stimulatory effect of insulin on collagenase gene transcription in MES 13 cells, suggesting that activation of the MAP kinase pathway is necessary for mediating this effect of insulin. The potential significance of these observations with respect to a role for insulin in the pathophysiology of diabetic glomerulosclerosis is discussed.

\section{Materials and methods}

\section{Materials}

$\left[\alpha-{ }^{32} \mathrm{P}\right]$ dATP $(>3000 \mathrm{Ci} / \mathrm{mmol})$ and $\left[{ }^{3} \mathrm{H}\right]$ acetic acid, sodium salt $(>10 \mathrm{Ci} / \mathrm{mmol})$ were obtained from Amersham and ICN respectively. Insulin was purchased from Collaborative Bioproducts (Bedford, MA, USA). The MEK-1 and -2 inhibitor U0126 was purchased from Calbiochem (San Diego, CA, USA) or Promega. Specific antisera to c-fos (sc-52), Fra-1 (sc-183), Fra-2 (sc-604), c-jun (sc-45), Jun B (sc-46) and Jun D (sc-74) were all obtained from Santa Cruz Biotechnology Inc.,
Santa Cruz, CA, USA. All oligonucleotides were synthesized by the Vanderbilt University Medical Center Diabetes Core laboratory.

\section{Plasmid construction}

The construction of a human collagenasechloramphenicol acetyltransferase (CAT) fusion gene containing promoter sequence, relative to the transcription start site, from -518 to +64 in the pCAT(An) expression vector (Jacoby et al. 1989), has previously been described (Chapman et al. 1999). The pCAT(An) vector has polyadenylation signals located $5^{\prime}$ of the polylinker to prevent read-through transcription (Jacoby et al. 1989). Control experiments demonstrated that there was no basal CAT expression and no effect of insulin when the pCAT(An) vector, minus the collagenase promoter, was transiently transfected into MES 13 cells (data not shown). A series of truncated collagenase-CAT fusion genes, with the $5^{\prime}$ endpoints shown in Fig. 5, were generated using the - 518/+64 pCAT(An) construct as a template as previously described (Chapman et al. 1999). Similarly, a construct designated - 79 AP-1 SDM, containing a site-directed mutation (SDM) of the collagenase AP-1 motif in the context of the -79 to +64 promoter fragment (Fig. 5), was generated as previously described (Chapman et al. 1999).

A three-step PCR strategy (Higuchi et al. 1988) was used to introduce a site-directed mutation into the collagenase AP-1 motif within the context of the -518 to +64 collagenase promoter fragment. Briefly, two complementary PCR primers were designed to mutate four nucleotides within the collagenase AP-1 motif. The sequence of the sense strand oligonucleotide was as follows: 5'-GGATGT TATAAAGGAactaTCAGACAGCGTCTGGGTT TC-3'. The location of the AP-1 core sequence is underlined and the mutated nucleotides are in lower case. This sense strand oligonucleotide was used in conjunction with a $3^{\prime}$ PGR primer to generate the $3^{\prime}$ half of the collagenase promoter, whereas the complementary antisense strand oligonucleotide was used in conjunction with a $5^{\prime}$ PCR primer to generate the $5^{\prime}$ half of the collagenase promoter. These $5^{\prime}$ and $3^{\prime}$ primers were designed to maintain the $5^{\prime}$ and $3^{\prime}$ junctions of the collagenase promoter fragments to be the same as those in the wild-type -518 to +64 collagenase-CAT fusion gene construct. The PGR 
products from these two reactions were then combined and used themselves as both primer and template in a second PCR to generate a small amount of the full-length, mutated collagenase promoter fragment. Finally, the $5^{\prime}$ and $3^{\prime}$ PCR primers were then used to amplify this fragment. This fragment was ligated into the pGEM7 vector (Promega) and completely sequenced using the USB (Gleveland, OH, USA) Sequenase kit to ensure the absence of polymerase errors. The promoter fragment was then re-isolated and ligated into the pCAT(An) vector and the resulting construct was designated -518 AP-1 SDM (Fig. 6).

For primary human mesangial cell transfection experiments, the CAT reporter gene was replaced with the more sensitive firefly luciferase reporter gene. This was achieved by re-isolating the wild-type and AP-1 mutated -518 to +64 collagenase promoter fragments from the pCA$\mathrm{T}(\mathrm{An})$ expression vector using HindIII and XhoI and ligation into the polylinker of pGL3 MOD (Martin et al. 2003).

A plasmid, designated XMB, containing a minimal Xenopus laevis $68 \mathrm{kDa}$ albumin promoter ligated to the CAT reporter gene was generated as previously described (Chapman et al. 1999). Double-stranded complementary oligonucleotides, representing the wild type ( -78 AAGGATGAGT CAGACA - 63; AP-1 motif underlined) or mutated ( 78 AAGGAactaTGAGACA - 63; mutated bases in lower case letters) collagenase AP-1 motif were synthesized with HindIII compatible ends and ligated into HindIII-cleaved XMB in multiple copies as previously described (Chapman et al. 1999).

A fragment of the human MMP-9 promoter representing the sequence located between -600 to +6 was isolated using PCR in conjunction with the following 5' (5'-CGCAAGCTTGGAATTCG CGAGCGTTGCGTAGCAG-3') and $3^{\prime}$ (5'-CG GCTCGAGTGTCTGACTGCAGCTGCTGTT GTG-3') primers. HindIII and XhoI sites used for cloning purposes are underlined. This fragment was ligated into the pGEM-T vector and completely sequenced using the USB Sequenase kit to ensure the absence of polymerase errors. This promoter fragment was then re-isolated and ligated into the pGL3 MOD expression vector.

All plasmid constructs were purified by centrifugation through cesium chloride gradients (Sambrook et al. 1989).

\section{Cell culture and transient transfection}

Murine MES 13 kidney mesangial-derived cells were grown in a 1:1 mixture of Dulbecco's modified Eagle's medium (DMEM) and Ham's F-12 medium containing 10\% (v/v) fetal bovine serum and re-plated the day before use into six-well culture plates. Attached cells were then transiently transfected using the calcium phosphate-DNA co-precipitation method as previously described (Streeper et al. 1998, Chapman et al. 1999). Collagenase-CAT and MMP-9-luciferase fusion gene constructs $(2 \mu \mathrm{g} /$ well $)$ were co-transfected with expression vectors encoding $\beta$ galactosidase $(0 \cdot 5 \mu \mathrm{g} /$ well $)$ and the insulin receptor $(0 \cdot 8 \mu \mathrm{g} /$ well $)$. After an overnight incubation in DMEM/F-12 containing $10 \%(\mathrm{v} / \mathrm{v})$ fetal bovine serum, the medium was removed and the cells rinsed in PBS before incubation for a further $18-24 \mathrm{~h}$ in serum-free DMEM supplemented with or without insulin at the concentrations indicated in the Figure legends prior to harvesting. In one experiment (Fig. 8), attached MES 13 cells were co-transfected with a collagenase-CAT fusion gene construct ( $2 \mu \mathrm{g} /$ well) along with expression vectors encoding Bgalactosidase $(0.5 \mu \mathrm{g} /$ well $)$ and the insulin receptor $(0 \cdot 8 \mu \mathrm{g} /$ well $)$, using the lipofectamine reagent (Gibco-BRL, Invitrogen, Carlsbad, CA, USA) exactly as previously described (Bischof et al. 2001). The lipofectamine:DNA ratio was 5:1. After lipofectamine-mediated transfection, cells were then incubated for 18-24 h in serum-free DMEM in the presence or absence of $100 \mathrm{nM}$ insulin prior to harvesting.

Low passage primary human mesangial cells and mesangial cell growth medium (MsGM) were purchased from Cambrex Bio Science Inc. (Walkersville, MD, USA). Cells were grown in complete MsGM and re-plated the day before use into six-well culture plates. Attached cells were transiently co-transfected with collagenase-luciferase fusion gene constructs $(14 \mu \mathrm{g} /$ well $)$ along with an expression vector encoding Renilla luciferase $(0 \cdot 7 \mu \mathrm{g} /$ well $)$ and either an expression vector encoding the insulin receptor or the empty pcDNA3 vector $(2 \cdot 8 \mu \mathrm{g}$ /well $)$, using the lipofectamine reagent (Gibco-BRL) exactly as previously described (Bischof et al. 2001), except that the lipofectamine: DNA ratio was $0 \cdot 7: 1$. After lipofectamine-mediated transfection, cells were then incubated for 18-24 h in basal MsGM prior to harvesting. 
Liver-derived H4IIE cells and cervix-derived HeLa cells were cultured in DMEM supplemented with either $2.5 \%(\mathrm{v} / \mathrm{v})$ newborn bovine serum and $2.5 \%$ (v/v) fetal bovine serum or $10 \%$ (v/v) newborn bovine serum respectively.

\section{CAT, $\beta$ galactosidase and luciferase assays}

Transfected MES 13 cells were harvested by trypsin digestion and sonicated in $150 \mu \mathrm{l} 250 \mathrm{mM}$ Tris (pH 7•8) containing $2 \mathrm{mM}$ phenylmethylsulfonyl fluoride (PMSF). CAT and $\beta$ galactosidase assays were performed as previously described (O'Brien et al. 1995a,b). To compare the relative basal CAT expression obtained with the various reporter gene constructs described, CAT activity in samples from control cells was corrected for the $\beta$ galactosidase activity in the same sample. Transfected primary mesangial cells were harvested using passive lysis buffer (Promega) and both firefly and Renilla luciferase activity were then assayed using the dual luciferase assay kit (Promega) as previously described (Martin et al. 2002). To correct for variations in transfection efficiency, the results are expressed as a ratio of firefly to Renilla luciferase activity. Several independent preparations of each plasmid construct were analyzed in duplicate in multiple transfections, as specified in the Figure legends.

\section{Protein extraction, SDS-PAGE and immunodetection}

Whole cell extracts were generated from HeLa, H4 IIE, MES 13 and primary mesangial cells. Cells were rinsed in PBS and then harvested by scraping and subsequent centrifugation. The cell pellets were resuspended in $500 \mu \mathrm{l}$ Triton X-100 extraction buffer $(1 \cdot 0 \%$ Triton X-100, $300 \mathrm{mM} \mathrm{NaCl}$, $20 \mathrm{mM}$ Tris, $\mathrm{pH} \quad 7 \cdot 3$ and $10 \mathrm{mM}$ EDTA) supplemented with $1 \times$ Roche complete EDTAfree protease inhibitor cocktail. The cell suspensions were then forced through a 27 gauge needle and incubated on ice for $1 \mathrm{~h}$. Protein concentrations were then determined using the Bio-Rad protein assay system. Twenty micrograms of protein were then resolved on a $7 \cdot 0 \%$ SDSpolyacrylamide gel and subsequently transferred to a polyvinylidene fluoride membrane by semidry blotting in $25 \mathrm{mM}$ Tris, $192 \mathrm{mM}$ Glycine and 20\% methanol as previously described (Hutton et al.
1988). Immunoblot analysis was then performed using an insulin receptor $\beta$-subunit antiserum (Santa Cruz; sc-711) as the primary antibody and a goat anti-rabbit immunoglobulin $\mathrm{G}$ antiserum conjugated to horseradish peroxidase (Calbiochem) as the secondary antibody. Antibody binding was detected using the enhanced chemiluminesence detection kit (Amersham Biosciences) according to the manufacturer's instructions.

\section{Gel retardation assay}

\section{Labeled probes}

Oligonucleotides representing the sense and antisense strands of the wild-type collagenase AP-1 motif ( -78 AAGCATGAGTCAGACA - 63) were synthesized with BamHI compatible ends, gel purified, annealed and then labeled with $\left[\alpha-{ }^{32} \mathrm{P}\right] \mathrm{dATP}$ using the Klenow fragment of Escherichia coli DNA polymerase I to a specific activity of approximately $2.5 \mu \mathrm{Ci} / \mathrm{pmol}$.

\section{Nuclear extract preparation}

MES 13 cells were transiently transfected with an expression vector encoding the human insulin receptor using the calcium phosphate-DNA coprecipitation method, as described above. After an overnight incubation in DMEM/F-12 containing $10 \%$ (v/v) fetal bovine serum, the medium was replaced with serum-free DMEM supplemented with or without $100 \mathrm{nM}$ insulin. After a $5 \mathrm{~h}$ incubation, nuclear extracts were then prepared by the method of Andrews \& Faller (1991) except that cells were lysed using Nonidet (NP)-40 to isolate nuclei (Marzluff 1990). Briefly, cells were lysed in $10 \mathrm{mM}$ Tris- $\mathrm{HCl}, \mathrm{pH} 7 \cdot 4,10 \mathrm{mM} \mathrm{NaCl}, 3 \mathrm{mM}$ $\mathrm{MgCl}_{2}, 0.5 \%$ NP-40, 0.5 mM dithiothreitol (DTT) and $0.5 \mathrm{mM}$ PMSF and the isolated nuclei were extracted using $20 \mathrm{mM}$ HEPES, pH 7.8, 0.4 M $\mathrm{NaCl}, 0.75 \mathrm{mM}$ spermidine, $0.15 \mathrm{mM}$ spermine, $0.2 \mathrm{mM}$ EDTA, $2 \mathrm{mM}$ EGTA, 25\% glycerol, $2 \mathrm{mM}$ DTT and $1 \mathrm{mM}$ PMSF. The protein concentration of the nuclear extracts was determined using the Bio-Rad assay.

\section{Standard AP-1 binding assay}

Labeled AP-1 oligonucleotide $(\sim 7.5 \mathrm{fmol}$, $\sim 30000$ c.p.m.) was incubated with MES 13 nuclear extract $(0 \cdot 5-2 \mu \mathrm{g})$ in a final reaction volume 
of $20 \mu \mathrm{l}$ containing $20 \mathrm{mM}$ HEPES, $\mathrm{pH} 7 \cdot 8$, $100 \mathrm{mM} \mathrm{NaCl}, 0.38 \mathrm{mM}$ spermidine, $0.08 \mathrm{mM}$ spermine, $0 \cdot 1 \mathrm{mM}$ EDTA, $1 \mathrm{mM}$ EGTA, $2 \mathrm{mM}$ DTT, $12.5 \%$ glycerol $(\mathrm{v} / \mathrm{v})$ and $1 \mu \mathrm{g}$ poly $(\mathrm{dI}-$ $\mathrm{dC}) \times \operatorname{poly}(\mathrm{dI}-\mathrm{dC})$. After incubation for $10 \mathrm{~min}$ at room temperature, the reactants were loaded onto a $6 \%$ polyacrylamide gel and electrophoresed at room temperature for $90 \mathrm{~min}$ at $150 \mathrm{~V}$ in a buffer containing $25 \mathrm{mM}$ Tris- $\mathrm{HCl}, \mathrm{pH} 7 \cdot 8,190 \mathrm{mM}$ glycine and $1 \mathrm{mM}$ EDTA. Following electrophoresis, the gels were dried, exposed to Kodak XAR5 film, and binding was analyzed by autoradiography.

\section{Competition experiments}

For competition experiments (Fig. 10) the indicated unlabeled double-stranded oligonucleotides (100fold molar excess) were mixed with the labeled oligomer prior to addition of nuclear extract $(0.5 \mu \mathrm{g})$. Binding was then analyzed as described above.

\section{Gel supershift}

Gel supershift assays (Fig. 11) were carried out by incubating MES 13 nuclear extract $(2 \mu \mathrm{g})$ with the indicated antisera $(1 \mu \mathrm{g})$ for $10 \mathrm{~min}$ at room temperature, prior to the addition of the labeled AP-1 oligonucleotide probe and binding buffer and incubation for an additional $10 \mathrm{~min}$ at room temperature. Binding was then analyzed as described above.

\section{Results}

\section{Insulin stimulates collagenase-CAT fusion gene transcription in MES 13 cells}

To begin to study the regulation of collagenase gene transcription by insulin in mesangial cells, a collagenase-CAT fusion gene construct, containing collagenase promoter sequence from -518 to +64 , was transiently transfected into MES 13 cells. These cells represent a mesangial cell line model and are derived from glomerula explants of mice transgenic for the transforming gene encoding large $\mathrm{T}$-antigen, which is present in the early region of simian virus 40 (SV40) (MacKay et al. 1988). MES 13 cells exhibit several of the biochemical and morphological features of normal mesangial

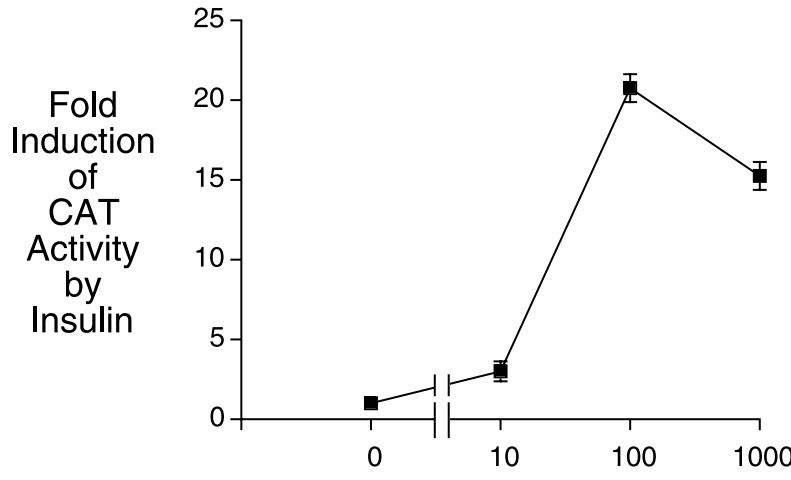

Insulin Concentration (nM)

Figure 1 Concentration dependence of insulin-stimulated collagenase-CAT fusion gene transcription in MES 13 cells. MES 13 cells were transiently co-transfected using calcium phosphate co-precipitation, as described in Materials and methods, with a collagenase-CAT fusion gene $(2 \mu \mathrm{g})$, containing promoter sequence from -518 to +64 , and expression vectors encoding $\beta$ galactosidase $(0.5 \mu \mathrm{g})$ and the insulin receptor $(0.8 \mu \mathrm{g})$. Following transfection, cells were incubated for 18-24 $\mathrm{h}$ in serum-free media, in the presence or absence of the indicated concentration of insulin. The cells were then harvested and both CAT and $\beta$ galactosidase activities were assayed as described in Materials and methods. Results are presented as the ratio of CAT:ßgalactosidase activity in insulin-treated versus control cells and are expressed as fold induction. Results represent the means \pm S.E.M. of three experiments using several independent preparations of the fusion gene construct, assayed in duplicate.

cells in culture (MacKay et al. 1988, Robey et al. 1999, Maile et al. 2000, Coy et al. 2002). As seen in Fig. 1, insulin markedly stimulated collagenase-CAT fusion gene transcription in this cell line with a maximal effect at a concentration of $100 \mathrm{nM}$. Insulin also stimulated MMP-9-luciferase fusion gene transcription in MES 13 cells (Fig. 2) though the magnitude of the insulin effect ( $\sim 3$-fold) was much less than that seen on collagenase-CAT fusion gene transcription $(\sim 20$ fold; Fig. 1).

As reported previously for HeLa cells (Chapman et al. 1999), this effect of insulin on collagenaseCAT fusion gene transcription in MES 13 cells was only observed following co-transfection with an expression vector encoding the insulin receptor (Fig. 3A). In the absence of insulin, co-transfection with the insulin receptor alone was insufficient to activate collagenase-CAT fusion gene transcription 


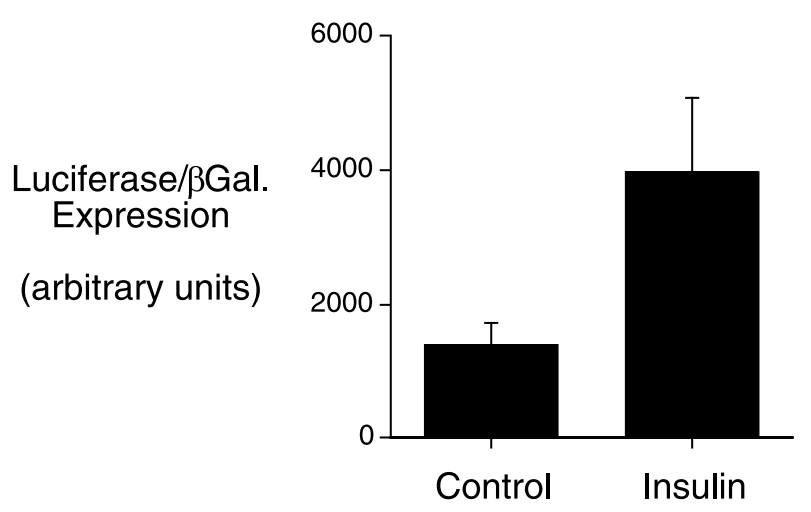

Figure 2 Insulin stimulates MMP-9-luciferase fusion gene transcription in MES 13 cells. MES 13 cells were transiently co-transfected using calcium phosphate co-precipitation, as described in Materials and methods, with an MMP-9-luciferase fusion gene $(2 \mu \mathrm{g})$, containing promoter sequence from -600 to +6 , and expression vectors encoding $\beta$ galactosidase $(0.5 \mu \mathrm{g})$ and the insulin receptor $(0.8 \mu \mathrm{g})$. Following transfection, cells were incubated for 18-24 $\mathrm{h}$ in serum-free medium in the presence or absence of $100 \mathrm{nM}$ insulin. The cells were then harvested and both luciferase and $\beta$ galactosidase activity were assayed as described in Materials and methods. Results are presented as the ratio of luciferase: $\beta$ galactosidase ( $\beta$ Gal.) activity and are expressed as arbitrary units. Results represent the means \pm S.E.M. of three experiments with all samples assayed in duplicate.

in MES 13 cells, suggesting a low level of signaling through the basal receptor (Fig. 3B).

The requirement for insulin receptor cotransfection to manifest an insulin response suggests that MES 13 cells no longer express endogenous insulin receptors because insulin receptors are normally present in mesangial cells (Abrass et al. 1988, Arnqvist et al. 1988) and their numbers increase in the diabetic state (Oemar et al. 1991). Similarly, human cervix, from which HeLa cells are derived, also expresses insulin receptors (Sheets et al. 1985), suggesting that endogenous insulin receptor expression is also lost in HeLa cells. Surprisingly, Fig. 4 shows that endogenous insulin receptors are expressed in both MES 13 and HeLa cells. The antiserum used in this analysis is specific for the insulin receptor and does not cross-react with IGF-I or insulin-related receptors. The requirement for co-transfection of an insulin receptor expression vector to study insulinregulated collagenase gene expression in MES 13 and HeLa cells suggests that, even though these cells express endogenous insulin receptors, they are
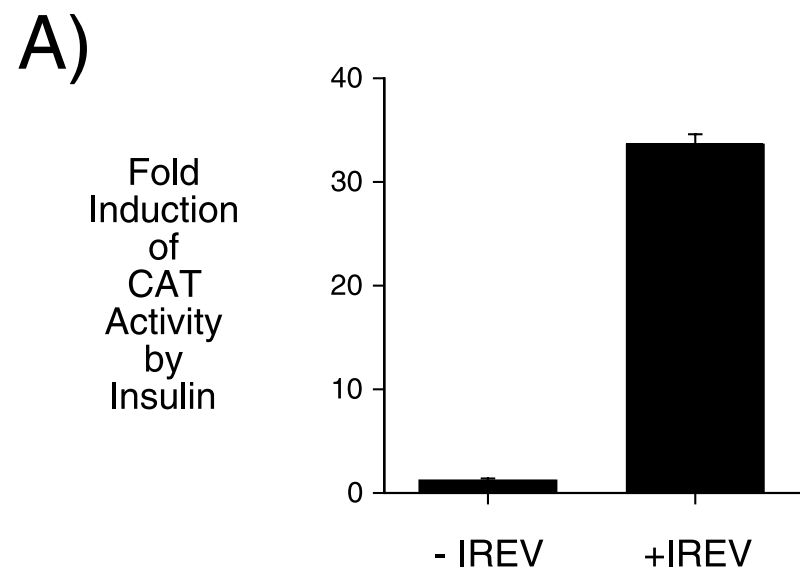

B)

CAT/ $\beta$ Gal. Expression in Control Cells

(arbitrary units)

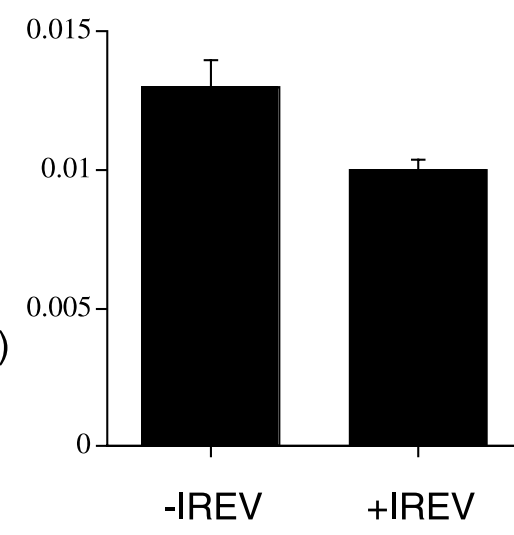

Figure 3 Insulin-stimulated collagenase-CAT fusion gene transcription in MES 13 cells requires the insulin receptor. MES 13 cells were transiently co-transfected using calcium phosphate co-precipitation, as described in Materials and methods, with a collagenase-CAT fusion gene $(2 \mu \mathrm{g})$, containing promoter sequence from -518 to +64 , an expression vector encoding Bgalactosidase $(0.5 \mu \mathrm{g})$ and either with (+IREV) or without (-IREV) an expression vector encoding the insulin receptor $(0.8 \mu \mathrm{g})$. Following transfection, cells were incubated for 18-24 $\mathrm{h}$ in serum-free medium in the presence or absence of $100 \mathrm{nM}$ insulin. The cells were then harvested and both CAT and $\beta$ galactosidase activity were assayed as described in Materials and methods. In (A) results are presented as the ratio of CAT:Bgalactosidase activity in insulin-treated versus control cells and are expressed as fold induction. In (B) results are presented as the ratio of CAT: $\beta$ galactosidase ( $\beta$ Gal.) activity in control cells and are expressed as arbitrary units. Results represent the means \pm S.E.M. of three experiments using several independent preparations of the fusion gene construct, assayed in duplicate. 


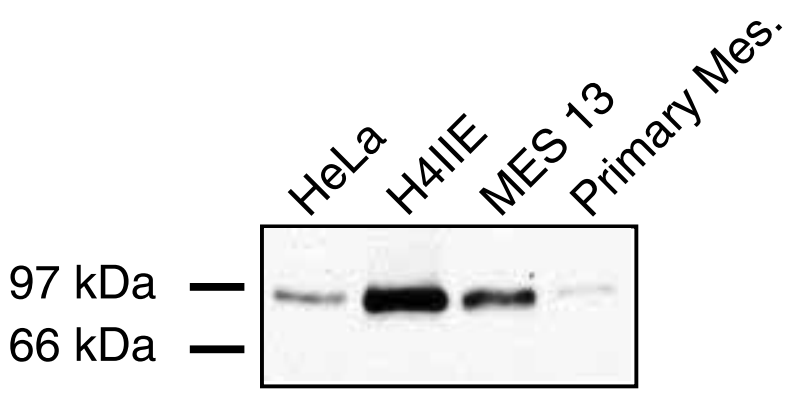

Figure 4 MES 13 cells express endogenous insulin receptors. Insulin receptor expression in MES 13, H4IIE and HeLa cells, as well as in primary mesangial (Mes.) cells, was analyzed by immunoblot analysis as described in Materials and methods.

non-functional. Figure 4 also demonstrates that insulin receptors are expressed in primary mesangial cells as well as in rat H4IIE hepatoma cells. Insulin-regulated gene expression has been extensively studied in H4IIE cells without a requirement for co-transfection of an insulin receptor expression vector (O'Brien \& Granner 1996).

\section{Multiple promoter elements are required for the stimulatory effect of insulin on collagenase fusion gene transcription in MES 13 cells}

Although in the streptozotocin rat model of type I diabetes, the glomerula expression of collagenase, MMP-2 and MMP-9 are all decreased (Nakamura et al. 1994, McLennan et al. 2002), the former MMP is associated with degradation of type 1 collagen whereas type 4 collagen is the principal collagen to accumulate in the glomerulus in diabetic nephropathy (Mauer 1994). Type 4 collagen is a substrate for MMP-2 and MMP-9 (Nagase \& Woessner 1999, Brinckerhoff \& Matrisian 2002). This suggests that MMP-2 and MMP-9, rather than collagenase, could play a major role in the regulation of ECM accumulation in diabetic nephropathy. However, in this study we chose to focus on identifying the promoter elements through which insulin stimulates collagenase fusion gene expression in MES 13 cells, given that the magnitude of the effect of insulin on collagenase (Fig. 1) was much greater than that on MMP-9 (Fig. 2).

To identify the promoter elements that mediate the stimulatory effect of insulin on collagenase fusion gene transcription in MES 13 cells, a series of $5^{\prime}$ truncated collagenase-CAT fusion genes were
A)

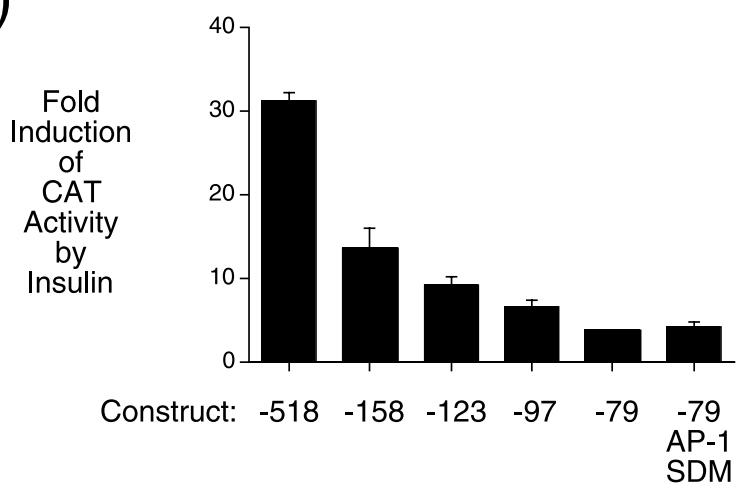

B)

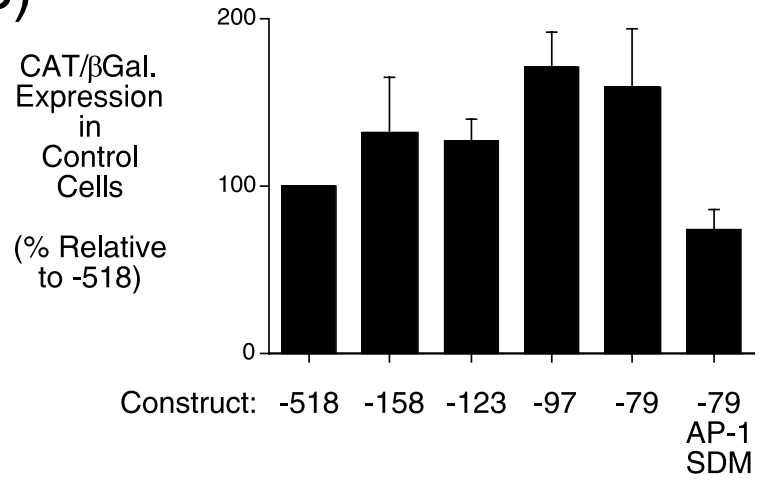

Figure 5 Progressive deletion of the collagenase promoter sequence between -518 and -80 reduces the stimulatory effect of insulin on collagenase-CAT fusion gene transcription. MES 13 cells were transiently co-transfected using calcium phosphate co-precipitation, as described in Materials and methods, with a series of collagenase-CAT fusion genes $(2 \mu \mathrm{g})$, with $5^{\prime}$ deletion end-points as shown on the abscissa, and expression vectors encoding $\beta$ galactosidase $(0.5 \mu \mathrm{g})$ and the insulin receptor $(0.8 \mu \mathrm{g})$. Following transfection, cells were incubated for 18-24 $\mathrm{h}$ in serum-free media in the presence or absence of $100 \mathrm{nM}$ insulin. The cells were then harvested and both CAT and $\beta$ galactosidase activities were assayed as described in Materials and methods. Results in (A) are presented as the ratio of CAT: $\beta$ galactosidase activity in insulin-treated versus control cells and are expressed as fold induction. Results in (B) are presented as the ratio of CAT: $\beta$ galactosidase ( $\beta$ Gal.) activity in control cells and are expressed as a percentage relative to the $-5185^{\prime}$ deletion construct. Results represent the means \pm S.E.M. of three experiments using several independent preparations of each fusion gene construct, in which each construct was assayed in duplicate.

transiently transfected into MES 13 cells and the effect of insulin on CAT expression directed by these constructs was analyzed. Figure 5A shows 
that progressive deletion of the collagenase promoter sequence between -518 and -79 resulted in a progressive decrease in insulinstimulated collagenase-CAT fusion gene transcription (Fig. 5A) with little change in basal fusion gene transcription (Fig. 5B). This result suggested that either multiple independent IRSs are present in the collagenase promoter region between -518 and -79 or that this promoter region contains binding sites for multiple accessory factors that enhance the action of insulin mediated through a more proximal IRS. Indeed, we have previously shown that an AP-1 motif, located between -73 and -67 , is important for the stimulation of collagenase-CAT fusion gene transcription by insulin in HeLa cells (Chapman et al. 1999). The -79 to +64 collagenase promoter region does confer an $\sim 4$-fold stimulation of CAT expression by insulin but when this AP-1 motif was mutated in the context of the -79 to +64 collagenase promoter fragment it had no effect on the insulin response (Fig. 5A; - 79 AP-1 SDM), though basal fusion gene expression decreased slightly (Fig. 5B).

This result would appear to indicate that the collagenase AP-1 motif is not important for insulin-stimulated collagenase-CAT fusion gene transcription in MES 13 cells. However, it is becoming increasingly apparent that the analysis of cis-acting elements in the context of truncated promoter fragments can be misleading, such that the importance of individual elements may only be apparent in the context of an otherwise intact promoter (Fry \& Farnham 1999, Falvo et al. 2000). To address this possibility, the collagenase AP-1 motif was mutated in the context of the -518 to +64 collagenase promoter region. Figure 6 shows that mutation of the AP-1 motif in this context dramatically reduced basal collagenase-CAT fusion gene expression (Fig. 6A) and abolished the stimulatory effect of insulin (Fig. 6B). In contrast to the conclusion reached through the analysis of the truncated collagenase promoter (Fig. 5), this result indicated that the collagenase AP-1 motif is critical for both basal and insulin-stimulated collagenaseCAT fusion gene transcription in MES 13 cells.

Given this marked difference in results depending on whether the collagenase AP-1 motif was studied in the context of the $-518 /+64$ or $-79 /+64$ collagenase promoter fragments, we repeated this analysis in HeLa cells. We had previously shown that, in contrast to MES 13 cells

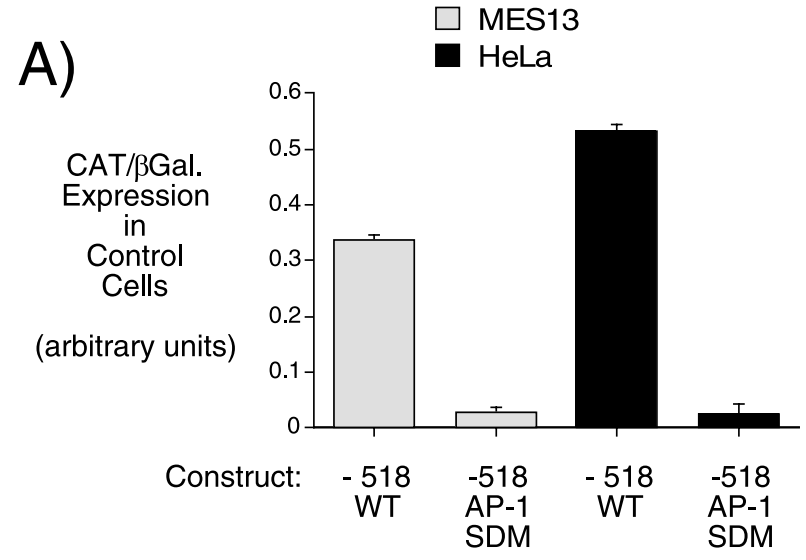

B)

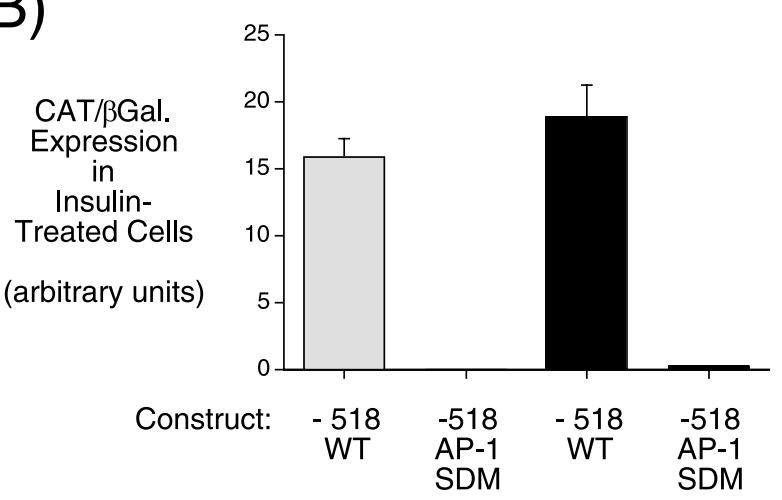

Figure 6 An AP-1 motif is required for basal and insulin-stimulated collagenase-CAT fusion gene transcription in both MES 13 cells (shaded bars) and HeLa cells (solid bars). MES 13 cells and HeLa cells were transiently co-transfected using calcium phosphate co-precipitation, as described in Materials and methods, with expression vectors encoding $\beta$ galactosidase $(0.5 \mu \mathrm{g})$ and the insulin receptor $(0.8 \mu \mathrm{g})$, and either a collagenase-CAT fusion gene $(2 \mu \mathrm{g})$ containing promoter sequence from -518 to +64 ( -518 wild type (WT)) or the same fusion gene with an SDM of the AP-1 motif ( -518 AP-1 SDM). Following transfection, cells were incubated for 18-24 $\mathrm{h}$ in serum-free media in the presence or absence of $100 \mathrm{nM}$ insulin. The cells were then harvested and both CAT and $\beta$ galactosidase activities were assayed as described in Materials and methods. In (A and $B)$ results are presented as the ratio of CAT: $\beta$ galactosidase ( $\beta$ Gal.) activity in either control or insulin-treated cells respectively, and are expressed as arbitrary units. Results represent the means \pm S.E.M. of three experiments using several independent preparations of each fusion gene construct, in which each construct was assayed in duplicate.

(Fig. 5B), deletion of the collagenase promoter region between -518 and -79 resulted in a progressive decrease in basal collagenase-CAT 
fusion gene expression in HeLa cells (Chapman et al. 1999). Moreover, again in contrast to MES 13 cells (Fig. 5B), mutation of the collagenase AP-1 motif in the context of the -79 to +64 collagenase promoter fragment almost completely abolishes basal collagenase-CAT fusion gene expression in HeLa cells (Chapman et al. 1999). Nevertheless, despite these differences between MES 13 and HeLa cells, mutation of the collagenase AP-1 motif in the context of the -518 to +64 promoter fragment dramatically reduced basal collagenaseCAT fusion gene expression (Fig. 6A) and abolished the stimulatory effect of insulin (Fig. 6B) in both MES 13 and HeLa cells. This result would appear to indicate that the collagenase AP-1 motif is critical for both basal and insulin-stimulated collagenase-CAT fusion gene transcription in both MES 13 and HeLa cells.

\section{The collagenase AP-1 motif is essential for high basal fusion gene expression in primary human mesangial cells}

Although MES 13 cells exhibit several of the biochemical and morphological features of normal mesangial cells in culture (MacKay et al. 1988, Robey et al. 1999, Maile et al. 2000, Coy et al. 2002), the need to express insulin receptors in these cells so as to study insulin action indicates that they do not entirely mimic the behavior of mesangial cells in vivo. We therefore investigated the regulation of collagenase fusion gene expression in primary human mesangial cells. Figure 7 shows that the collagenase AP-1 motif is also critical for basal collagenase-luciferase fusion gene transcription in primary human mesangial cells as it is in MES 13 and HeLa cells. Thus, mutation of the collagenase AP-1 motif in the context of the -518 to +64 promoter fragment dramatically reduced basal collagenase-luciferase fusion gene expression (Fig. 7). In contrast to MES 13 cells, no collagenaseluciferase fusion gene expression or SV40-Renilla luciferase expression was detected when these primary human mesangial cells were transfected using the calcium phosphate-DNA co-precipitation method (data not shown). While expression was detected using the lipofectamine transfection method (Fig. 7) there was no effect of insulin on collagenase-luciferase fusion gene expression, even in the presence of co-transfected insulin receptors.

We believe that this lack of insulin-regulated

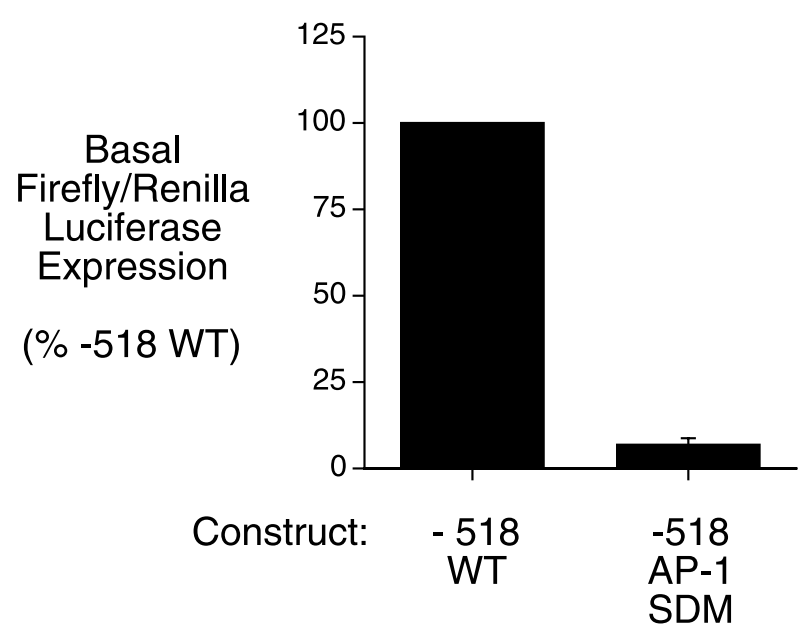

Figure 7 The collagenase AP-1 motif is also required for high basal collagenase-luciferase fusion gene transcription in primary human mesangial cells. Primary human mesangial cells were transiently co-transfected using lipofectamine, as described in Materials and methods, with either a collagenase-luciferase fusion gene $(14 \mu \mathrm{g})$ containing promoter sequence from -518 to $+64(-518 \mathrm{WT})$ or the same fusion gene with an SDM of the AP-1 motif ( -518 AP-1 SDM) along with an expression vector encoding Renilla luciferase $(0.7 \mu \mathrm{g})$ and the empty pcDNA3 vector $(2.8 \mu \mathrm{g} /$ well $)$. Following transfection, cells were incubated for 18-24 $\mathrm{h}$ in serum-free medium. The cells were then harvested and both firefly and Renilla luciferase activity were assayed as described in Materials and methods. Results are presented as the ratio of firefly:Renilla luciferase activity and are expressed as arbitrary units. Results represent the means \pm S.E.M. of three experiments each using an independent preparation of each fusion gene construct, assayed in triplicate.

collagenase-luciferase fusion gene expression reflects a technical problem with the use of lipofectamine for transfection rather than an inherent difference between MES 13 cells and primary human mesangial cells. Thus, the magnitude of insulin-stimulated collagenase-CAT fusion gene transcription was much greater when MES 13 cells were transiently transfected using the calcium phosphate co-precipitation method than when transfected using lipofectamine (Fig. 8A). An analysis of basal collagenase-CAT fusion gene transcription in MES 13 cells revealed that the use of lipofectamine markedly enhanced basal fusion gene transcription (Fig. 8B). This observation suggested that the reason why insulin fails to stimulate collagenase-CAT fusion gene transcription after lipofectamine-mediated transfection is that transcription of the fusion gene is already fully 
activated. Therefore, insulin treatment has little additional effect. By contrast, basal collagenaseCAT fusion gene transcription was relatively low after calcium phosphate-mediated transfection (Fig. 8B) but insulin treatment enhanced expression to a level similar to that obtained following lipofectamine-mediated transfection (Fig. 8C). We therefore hypothesized that insulin-regulated collagenase-luciferase fusion gene expression would be detected in primary human mesangial cells if it were possible to transfect these cells using the calcium phosphate co-precipitation method.

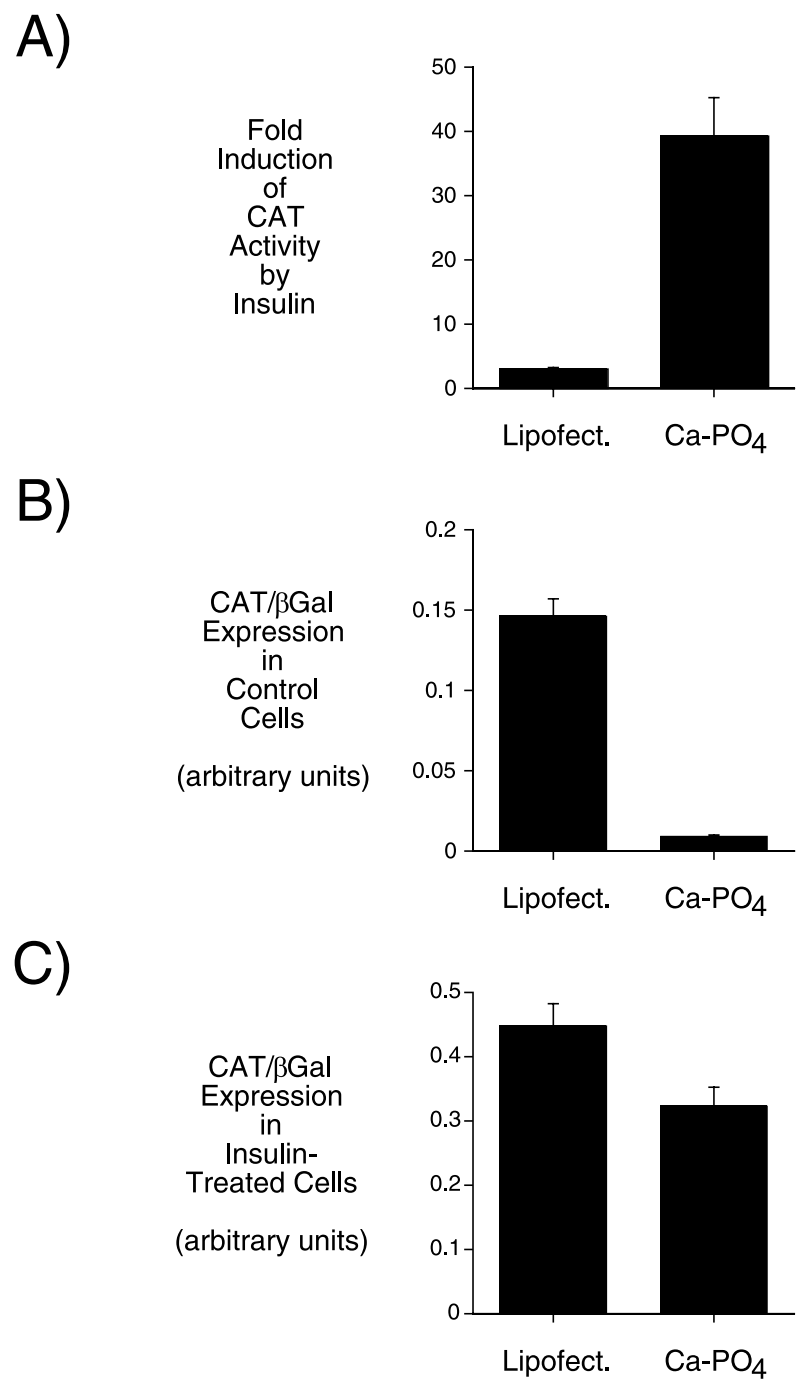

The collagenase AP-1 motif confers a stimulatory effect of insulin on the expression of a heterologous promoter

Although the preceding experiments demonstrated that the AP-1 motif is required for the action of insulin on collagenase fusion gene transcription (Fig. 6), they do not address the issue as to whether the AP-1 motif is a direct target of insulin signaling in MES 13 cells. It is possible that the AP-1 motif just acts as an accessory element to enhance the effects of insulin mediated through another element in the collagenase promoter. To address this question, multiple copies of a double-stranded oligonucleotide representing the collagenase AP-1 motif were ligated into the polylinker of a heterologous vector, designated $\mathrm{XMB}$, that contains a minimal Xenopus laevis $68 \mathrm{kDa}$ albumin promoter ligated to the CAT reporter gene (Chapman et al. 1999). The resulting construct, designated $\mathrm{A}(\mathrm{WT}) \mathrm{XMB}$, and the $\mathrm{XMB}$ vector were transiently transfected into MES 13 cells (Fig. 9). Neither basal CAT expression nor insulininduced CAT expression were detected with the $\mathrm{XMB}$ vector alone (Fig. 9). In contrast, the multimerized AP-1 motif was able to mediate an induction of fusion gene expression by insulin (Fig. 9). Mutation of the AP-1 motif in this context reduced basal fusion gene expression (Fig. 9B) and abolished the induction of $\mathrm{XMB}$ fusion gene

Figure 8 The magnitude of insulin-stimulated collagenase-CAT fusion gene transcription in MES 13 cells is influenced by the transfection method employed. MES 13 cells were either transiently co-transfected using calcium phosphate $\left(\mathrm{Ca}-\mathrm{PO}_{4}\right)$ co-precipitation or using lipofectamine (Lipofect.), as described in Materials and methods, with a collagenase-CAT fusion gene $(2 \mu \mathrm{g})$ containing promoter sequence from -518 to +64 , and expression vectors encoding $\beta$ galactosidase $(0.5 \mu \mathrm{g})$ and the insulin receptor $(0.8 \mu \mathrm{g})$. Following transfection, cells were incubated for $18-24 \mathrm{~h}$ in serum-free medium in the presence or absence of $100 \mathrm{nM}$ insulin. The cells were then harvested and both CAT and $\beta$ galactosidase activity were assayed as described in Materials and methods. In (A) results are

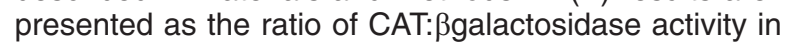
insulin-treated versus control cells and are expressed as fold induction. In (B and $\mathrm{C}$ ) results are presented as the ratio of CAT: $\beta$ galactosidase ( $\beta$ Gal.) activity in either control or insulin-treated cells respectively, and are expressed as arbitrary units. Results represent the means \pm S.E.M. of three experiments using several independent preparations of the fusion gene construct, assayed in duplicate. 


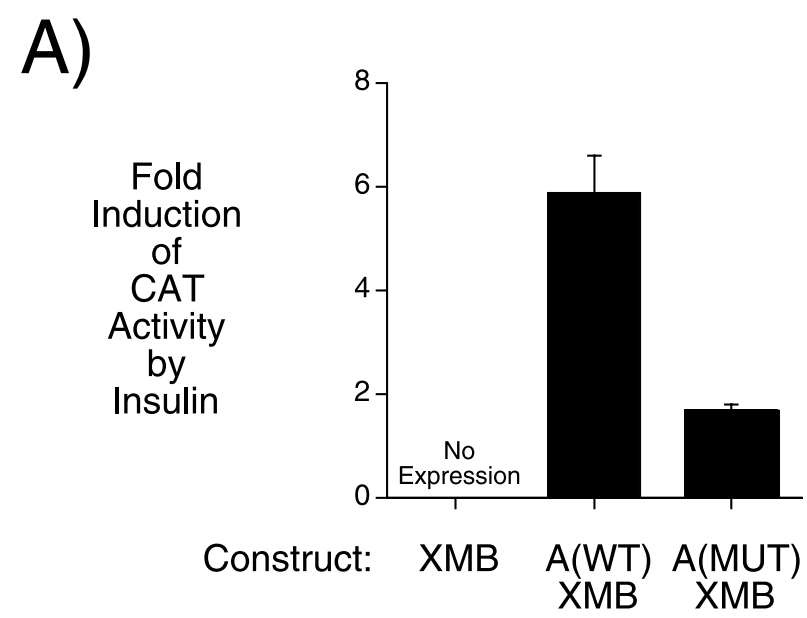

B)

\section{CAT/BGal. Expression in Control Cells} (arbitrary units)

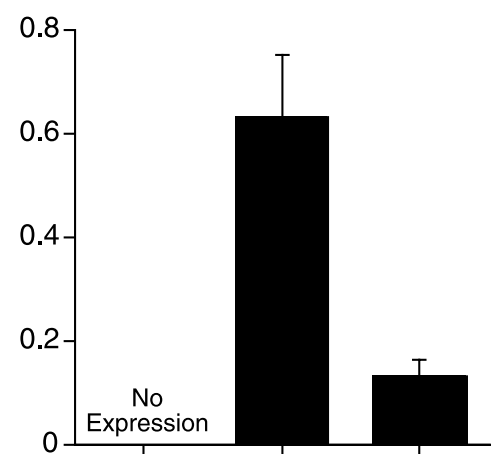

Construct: $\mathrm{XMB}$

\section{$\underset{\text { XMB }}{\mathrm{A}(\mathrm{WT})} \underset{\mathrm{XMB}}{\mathrm{A}(\mathrm{MUT})}$}

Figure 9 The collagenase AP-1 motif can confer a stimulatory effect of insulin on the expression of a heterologous Xenopus-CAT fusion gene. MES 13 cells were transiently co-transfected using calcium phosphate co-precipitation, as described in Materials and methods, with expression vectors encoding $\beta$ galactosidase $(0.5 \mu \mathrm{g})$ and the insulin receptor $(0.8 \mu \mathrm{g})$, and XMB vector constructs $(2 \mu \mathrm{g})$ in which oligonucleotides representing the wild-type or mutated collagenase AP-1 motif, designated $A(W T)$ and $A(M U T)$ respectively, had been ligated into the HindllI site of the Xenopus albumin promoter in multiple (four to five) copies. Following transfection, cells were incubated for 18-24 $\mathrm{h}$ in serum-free medium in the presence or absence of $100 \mathrm{nM}$ insulin. The cells were then harvested and both CAT and $\beta$ galactosidase activity were assayed as described in Materials and methods. In (A) results are presented as the ratio of CAT: $\beta$ galactosidase activity in insulin-treated versus control cells and are expressed as fold induction. In (B) results are presented as the ratio of CAT: $\beta$ galactosidase ( $\beta$ Gal.) activity in control cells and are expressed as arbitrary units. Results represent the means \pm S.E.M. of three experiments using several independent preparations of each fusion gene construct, assayed in duplicate. expression by insulin (Fig. 9A), just as it did in the context of the collagenase-CAT fusion gene (Fig. 6). This result suggested that the collagenase AP-1 motif is a direct target of insulin signaling in MES 13 cells.

\section{Protein binding to the collagenase AP-1 motif}

The gel retardation assay was used to analyze the specific binding of MES 13 nuclear extract proteins to the collagenase AP-1 motif (Fig. 10). A single major protein-DNA interaction was detected when a labeled double-stranded oligonucleotide representing collagenase promoter sequence from -78 to -63 , which contains the AP-1 motif between -73 and -67, was incubated with MES 13 nuclear extract (Fig. 10; see arrow). Competition experiments, in which a 100-fold molar excess of unlabeled DNA was included with the labeled probe, were used to correlate protein binding with the action of insulin on collagenase gene transcription. A 100-fold molar excess of the unlabeled -78/-63 oligonucleotide competed effectively against the labeled probe for binding of the protein(s) present in the major complex (Fig. 10). By contrast, an oligonucleotide representing the same -78 to -63 collagenase sequence, but with a mutation in the AP-1 core sequence that abolished insulin signaling through this element (Figs 6 and 9), failed to compete with the labeled probe for protein binding, even in a 100-fold molar excess (Fig. 10). This indicated that formation of this major complex represents a specific proteinDNA interaction that correlates with the effect of insulin mediated through this sequence in the context of the collagenase promoter (Fig. 6) and the heterologous XMB vector (Fig. 9).

Although AP-1 motifs can bind members of the Fos, Jun, Maf and activating transciption factor-2 (ATF) transcription factor families (Shaulian \& Karin 2002), we have previously shown that, when using HeLa (Streeper et al. 1998, Chapman et al. 1999) and H4IIE (Ayala et al. 2002) nuclear extract in gel retardation assays, the collagenase AP-1 motif primarily bound Fra-2 and Jun D. The effect of antibodies to members of the Fos and Jun family of proteins on the formation of the specific complex detected with the collagenase AP-1 motif when using MES 13 nuclear extract was therefore investigated. As can be seen in Fig. 11, addition of antibodies recognizing either Fra-1 or Jun D and, 


\section{Competitor: - WT MUT -}

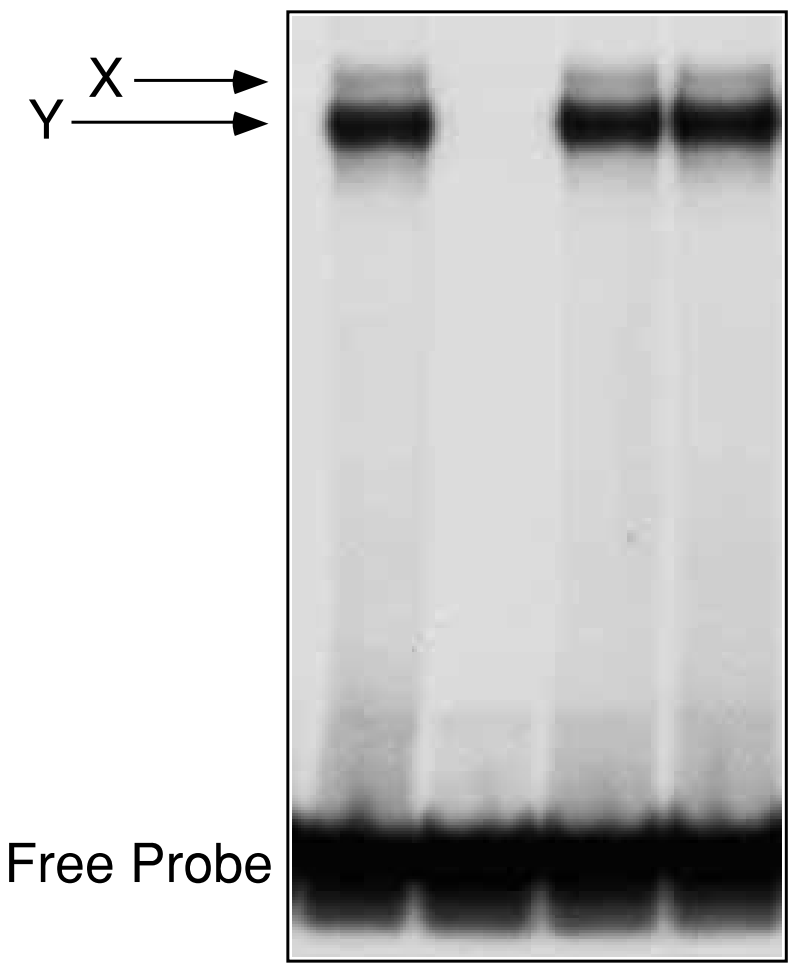

Figure 10 A specific protein-DNA complex was detected in gel retardation assays using the collagenase AP-1 motif as the labeled probe. Protein binding to a labeled oligonucleotide probe, representing the WT collagenase AP-1 motif (-78 AAGCATGAGTCAGACA -63; AP-1 motif underlined), was analyzed using MES 13 cell nuclear extracts and the gel retardation assay, as described in Materials and methods. The labeled probe were incubated in the absence (-) or presence of a 100-fold molar excess of unlabeled oligonucleotides representing either the WT or mutated (MUT; -78 AAGCAactaTCAGACA -63; mutated bases in lower case letters) collagenase AP-1 sequence prior to the addition of nuclear extract. A representative autoradiograph is shown.

to a lesser extent, Fra-2 and Jun B, all resulted in a selective retardation in the migration of the major complex, a so-called supershift. Since Fos proteins do not homodimerize (Angel \& Karin 1991, Shaulian \& Karin 2002), this suggested that the major complex binding the collagenase AP-1 motif in MES 13 cells is a heterodimer of Fra-1 and Jun D. There was no apparent change in the abundance or in the nature of the factors present in this complex when nuclear extracts were prepared from MES 13 cells that had been incubated for $5 \mathrm{~h}$ in the presence of insulin (Fig. 11).

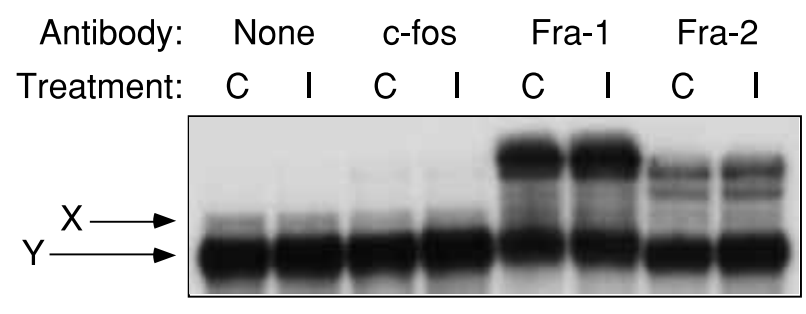

Antibody: None c-jun Jun B Jun D

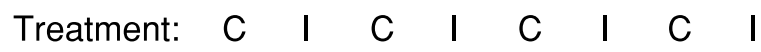

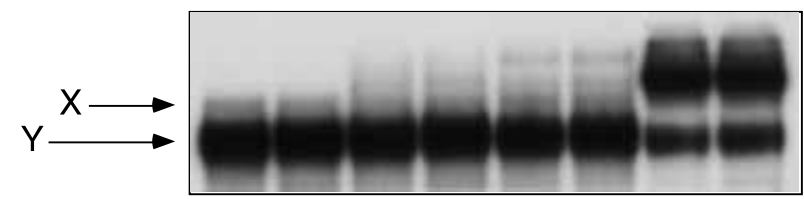

Figure $11 \mathrm{Fra}-1$ and Jun $\mathrm{D}$ are the predominant $\mathrm{AP}-1$ factors binding to the collagenase AP-1 motif in MES 13 nuclear extract. MES 13 cells were transiently transfected using calcium phosphate co-precipitation, as described in Materials and methods, with an expression vector encoding the insulin receptor $(0.8 \mu \mathrm{g})$. Nuclear extracts were then prepared from MES 13 cells incubated for $5 \mathrm{~h}$ in serum-free media $(C)$ or serum-free media supplemented with $100 \mathrm{nM}$ insulin (I). Nuclear extract $(2 \mu \mathrm{g})$ was preincubated in the absence of antibody (None) or in the presence of $1 \mu \mathrm{g}$ of the indicated antisera for $10 \mathrm{~min}$ at room temperature, prior to the addition of a labeled oligonucleotide probe, representing the collagenase promoter sequence between -78 and -63 , and binding buffer and incubation for an additional $10 \mathrm{~min}$ at room temperature. Protein binding was then analyzed using the gel retardation assay as described in Material and methods. In the representative autoradiograph shown, only the retarded complexes are visible and not the free probe, which was present in excess.

\section{A MEK-1 and -2 inhibitor blocks the stimulation of collagenase gene transcription by insulin in MES 13 cells}

Since insulin treatment did not seem to increase the mass of protein bound to the AP-1 motif, this suggested that the stimulatory effect of insulin on collagenase gene transcription in MES 13 cells may be mediated through post-translational modification of some or all of the proteins binding to the AP-1 motif. Rutter et al. (1995) have previously shown that, in CHO.T cells, overexpression of either a dominant negative form of MEK-1, the dual specificity protein kinase that phosphorylates and activates ERK1 and ERK2, or CL100, a MAP 


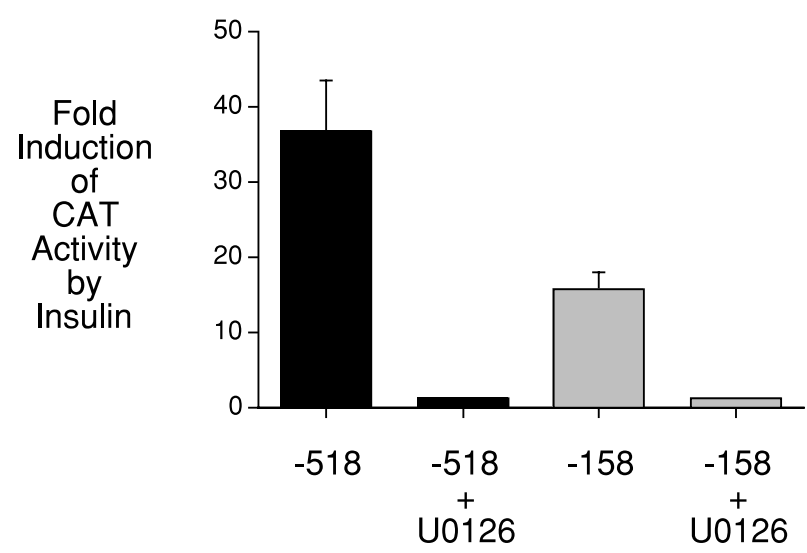

Figure 12 MAP kinase activation is required for the stimulatory effect of insulin on collagenase-CAT fusion gene transcription in MES 13 cells. MES 13 cells were transiently co-transfected using calcium phosphate co-precipitation, as described in Materials and methods, with expression vectors encoding $\beta$ galactosidase $(0.5 \mu \mathrm{g})$ and the insulin receptor $(0.8 \mu \mathrm{g})$, and with a collagenase-CAT fusion gene $(2 \mu \mathrm{g})$ containing either promoter sequence from -518 to +64 or from -158 to +64 . Following transfection, cells were incubated for 18-24 $\mathrm{h}$ in serum-free media, in the presence or absence of $100 \mathrm{nM}$ insulin and in the presence or absence of $10 \mu \mathrm{M}$ of the MEK-1 and -2 inhibitor U0126 as indicated. The cells were then harvested and both CAT and $\beta$ galactosidase activities were assayed as described in Materials and methods. Results are presented as the ratio of CAT: $\beta$ galactosidase activity in insulin-treated versus control cells, in the presence or absence of U0126, and are expressed as fold induction. Results represent the means \pm S.E.M. of three experiments using several independent preparations of each fusion gene construct, in which each construct was assayed in duplicate.

kinase phosphatase, inhibits the effect of insulin on collagenase fusion gene transcription. To determine whether activation of the MAP kinase pathway is necessary for stimulation of collagenaseCAT fusion gene transcription by insulin in MES 13 cells, we adopted an alternative approach and investigated the effect of U0126, a specific inhibitor of the dual specificity kinases MEK-1 and MEK-2 (Favata et al. 1998) (Fig. 12).

In vitro, $\mathrm{U} 0126$ inhibits $\mathrm{MEK}-1$ with an $\mathrm{IC}_{50}$ of $0.07 \mu \mathrm{M}$ and MEK-2 with an $\mathrm{IC}_{50}$ of $0.06 \mu \mathrm{M}$ (Duncia et al. 1998). However, in situ, U0126 undergoes isomerization and cyclization reactions that form various products, all of which exhibit less affinity for MEK (Duncia et al. 1998). Thus, U0126 maximally inhibits phorbol ester-stimulated, AP-1- dependent fusion gene expression in COS-7 cells in situ at $\sim 20 \mu \mathrm{M}$ (Favata et al. 1998). Similarly, U0126 maximally inhibits lysophosphatidic acid stimulation of hexokinase II activity in MES 13 cells in situ at $\sim 10 \mu \mathrm{M}$ with an $\mathrm{IC}_{50}$ of $0.4 \mu \mathrm{M}$ (Coy et al. 2002). MES 13 cells were transiently transfected with either the $-518 /+64$ or the $-158 /+64$ collagenase-CAT fusion gene constructs and the effect of insulin on CAT expression was assayed in cells incubated in the presence or absence of $10 \mu \mathrm{M}$ U0126 (Fig. 12). As seen in Fig. 12, the robust insulin-stimulated expression of CAT directed by both the $-518 /+64$ and the $-158 /+64$ fusion gene constructs was completely blocked in the presence of U0126. These results suggested that activation of the MAP kinase pathway is necessary for insulin-stimulated collagenase-CAT fusion gene transcription in MES 13 cells.

\section{Discussion}

The studies presented here sought to analyze the regulation of collagenase fusion gene transcription by insulin in the murine mesangial-derived MES 13 cell line. We have shown that insulin markedly stimulates collagenase fusion gene transcription in MES 13 cells (Fig. 1) and this effect requires an AP-1 motif in the collagenase promoter (Fig. 6), as it does in HeLa cells (Chapman et al. 1999). Some of the factors binding the AP-1 motif in MES 13 cells (Fig. 11) are distinct from those that bind the AP-1 motif in HeLa cells (Streeper et al. 1998, Chapman et al. 1999), though in both cases the action of insulin requires activation of the MAP kinase pathway (Fig. 12 and data not shown). Which of these AP-1-bound factors actually mediates the effect of insulin in MES 13 cells remains to be determined. Although this AP-1 motif can mediate an effect of insulin on heterologous fusion gene expression in MES 13 cells (Fig. 9), multiple other promoter elements are required for maximal insulin-stimulated collagenase fusion gene transcription and the AP-1 motif is unable to mediate an insulin response in their absence (Fig. 5). Since mutation of the AP-1 motif in the context of the otherwise intact collagenase promoter abolishes insulin-stimulated collagenase fusion gene transcription (Fig. 6), this suggested that these other promoter elements bind 
accessory factors that enhance insulin signaling through the AP-1 motif. Such an arrangement, referred to as a hormone response unit, is common with respect to cAMP- and glucocorticoidregulated gene transcription (Lucas \& Granner 1992, Roesler \& Park 1998). Although multiple other promoter elements are also required for maximal insulin-stimulated collagenase fusion gene transcription in HeLa cells (Chapman et al. 1999), the accessory element(s) located between -518 and -158 (Fig. 5) is uniquely important in MES 13 cells. Analysis of this promoter region using the MatInspector software (Quandt et al. 1995) identified multiple potential cis-acting elements. These include binding sites for chicken ovalbumin upstream promoter-transcription factor and hepatocyte nuclear factor-1. Both of these factors are expressed in the kidney (Baumhueter et al. 1990, Suzuki et al. 2000) and both have been previously shown to physically interact with members of the AP-1 transcription factor family (Leu et al. 2001, Lin et al. 2002).

The Diabetes Control and Complications Trial demonstrated that tight glycemic control markedly reduced the development of complications associated with type I diabetes, including diabetic nephropathy (Grofford 1995). Tight control was achieved through an increased frequency of insulin administration (Crofford 1995). Since the subjects undergoing intensive insulin therapy and standard insulin therapy both received a similar total amount of insulin (Crofford 1995), whereas hyperglycemia and complications were reduced in the intensive insulin therapy group, it might appear that hyperglycemia is the primary risk factor for the development of diabetic complications. However, although both groups received a similar total amount of insulin it is apparent, from the improved glycemic control, that insulin was clearly more efficacious in the intensive insulin therapy group. As such, it is not possible to exclude a role for reduced insulin action in the development of diabetic complications. In situ studies clearly demonstrate that high glucose levels do decrease MMP gene expression in cultured mesangial cells (Lenz et al. 2000). Moreover, the mechanisms by which hyperglycemia leads to decreased mesangial MMP gene expression have been intensively investigated (for reviews see Sheetz \& King 2002, Mason \& Wahab 2003). However, based on the results presented here, we hypothesize that, in type
I diabetes, reduced insulin action in mesangial cells may also directly contribute to the decreased collagenase gene expression characteristic of diabetic glomerulosclerosis. This hypothesis may have a broader significance since AP-1 motifs are important for the expression of the genes encoding several matrix metalloproteinases other than collagenase (Vincenti 2001). These include both MMP-2 and MMP-9 whose glomerula expression, like that of collagenase, is also decreased in type I diabetes (Nakamura et al. 1994, McLennan et al. 2002). Although the synthesis of MMP-2 was widely considered, in contrast to collagenase and MMP-9, to be independent of AP-1 (Benbow \& Brinckerhoff 1997, Westermarck \& Kahari 1999), it has recently been shown that MMP-2 is regulated through a non-consensus AP-1 motif that binds members of the AP-1 transcription factor family (Bergman et al. 2003). Interestingly, if insulin does directly regulate collagenase gene expression in mesangial cells in vivo then collagenase expression would actually be predicted to be increased in individuals who are hyperinsulinemic as a consequence of insulin resistance, since the insulin resistance associated with muscle, adipose tissue and liver may not be manifest in the kidney (Reaven 1997). Moreover, even in tissues where insulin resistance develops, it appears that insulin signaling through the PI3-kinase pathway is differentially affected (Cusi et al. 2000) rather than the MAP kinase pathway through which insulin regulates collagenase gene expression (Fig. 12).

In summary, the studies presented here have demonstrated that insulin stimulates collagenase fusion gene transcription in mesangial-derived MES 13 cells through an AP-1 motif. Future studies will investigate whether insulin also regulates endogenous collagenase gene expression in primary mesangial cells. It will be of particular interest to use these cells to compare the regulation of MMP gene expression by insulin and IGF-I. IGF-I has been reported to inhibit, rather than stimulate, MMP gene expression in primary mesangial cells (Lupia et al. 1999). Thus, it is possible that the regulation of MMP gene expression in mesangial cells represents one of the rare examples of the differential regulation of gene expression by insulin and IGF-I that exist despite the similarities in their signaling pathways (Siddle et al. 2001, Kim \& Accili 2002). 


\section{Acknowledgements}

We thank Howard Towle and Jonathan Whittaker for the pCAT(An) and insulin receptor expression vector plasmids respectively. We thank Ray Harris, Howard Crawford, Lynn Matrisian and David Dickerson for interesting discussions on the potential role of decreased collagenase gene expression in the pathophysiology of glomerulosclerosis and Enyu Imai for advice on primary mesangial cell transfections. We also thank Jeremy Tavaré and Ingeborg Hers for advice on insulin receptor Western blotting. HeLa cells were kindly provided by Roland Stein and Eva Henderson. This research was supported by grants from the NIH (RO1 DK52820 to R O'B), the National Kidney Foundation of Illinois (to R B R), the American Heart Association of Metropolitan Chicago (to R B R), as well as a Merit Review Award from the US Department of Veterans Affairs (to R B R). J E A was supported by the Vanderbilt Molecular Endocrinology Training Program (5 T 32 DK07563-12).

\section{References}

Abrass CK, Raugi GJ, Gabourel LS \& Lovett DH 1988 Insulin and insulin-like growth factor I binding to cultured rat glomerular mesangial cells. Endocrinology 123 2432-2439.

Andrews NC \& Faller DV 1991 A rapid micropreparation technique for extraction of DNA-binding proteins from limiting numbers of mammalian cells. Nucleic Acids Research 192499.

Angel P \& Karin M 1991 The role of Jun, Fos and the AP-1 complex in cell-proliferation and transformation. Biochimica et Biophysica Acta 1072 129-157.

Arnqvist HJ, Ballermann BJ \& King GL 1988 Receptors for and effects of insulin and IGF-I in rat glomerular mesangial cells. American Fournal of Physiology 254 C411-C416.

Ayala JE, Streeper RS, Svitek CA, Goldman JK, Oeser JK \& O'Brien RM 2002 Accessory elements, flanking DNA sequence, and promoter context play key roles in determining the efficacy of insulin and phorbol ester signaling through the malic enzyme and collagenase-1 AP-1 motifs. Fournal of Biological Chemistry 277 27935-27944.

Baumhueter S, Mendel DB, Conley PB, Kuo CJ, Turk C, Graves MK, Edwards CA, Courtois G \& Crabtree GR 1990 HNF-1 shares three sequence motifs with the POU domain proteins and is identical to LF-B1 and APF. Genes and Development 4 372-379.

Benbow U \& Brinckerhoff CE 1997 The AP-1 site and MMP gene regulation: what is all the fuss about? Matrix Biology 15 519-526.

Bergman MR, Cheng S, Honbo N, Piacentini L, Karliner JS \& Lovett DH 2003 A functional activating protein 1 (AP-1) site regulates matrix metalloproteinase 2 (MMP-2) transcription by cardiac cells through interactions with JunB-Fral and JunB-FosB heterodimers. Biochemical Fournal 369 485-496.

Birkedal-Hansen H 1993 Role of matrix metalloproteinases in human periodontal diseases. Fournal of Periodontology $\mathbf{6 4} 474-484$
Bischof LJ, Martin CC, Svitek CA, Stadelmaier BT, Hornbuckle LA, Goldman JK, Oeser JK, Hutton JC \& O'Brien RM 2001 Characterization of the mouse islet-specific glucose-6-phosphatase catalytic subunit-related protein gene promoter by in situ footprinting. Correlation with fusion gene expression in the islet derived bTG-3 and hamster insulinoma tumor cell lines. Diabetes $50502-514$

Borden P \& Heller RA 1997 Transcriptional control of matrix metalloproteinases and the tissue inhibitors of matrix metalloproteinases. Critical Reviews in Eukaryotic Gene Expression 7 159-178.

Brinckerhoff CE \& Matrisian LM 2002 Matrix metalloproteinases: a tail of a frog that became a prince. Nature Reviews. Molecular Cell Biology 3 207-214.

Chapman SC, Ayala JE, Streeper RS, Culbert AA, Eaton EM, Svitek CA, Goldman JK, Tavare JM \& O'Brien RM 1999 Multiple promoter elements are required for the stimulatory effect of insulin on human collagenase-1 gene transcription. Selective effects on activator protein-1 expression may explain the quantitative difference in insulin and phorbol ester action. Fournal of Biological Chemistry 274 18625-18634.

Choi BH, Park CJ \& Rho HM 1998 Insulin activates the hepatitis B virus $\mathrm{X}$ gene through the activating protein-1 binding site in HepG2 cells. DNA Cell Biology 17 951-956.

Coy PE, Taneja N, Lee I, Hecquet C, Bryson JM \& Robey RB 2002 LPA is a novel lipid regulator of mesangial cell hexokinase activity and HKII isoform expression. American Fournal of Physiology; Renal Physiology 283 F271-F279.

Creemers EE, Cleutjens JP, Smits JF \& Daemen MJ 2001 Matrix metalloproteinase inhibition after myocardial infarction: a new approach to prevent heart failure? Circulation Research $\mathbf{8 9}$ 201-210.

Crofford OB 1995 Diabetes control and complications. Annual Reviewes in Medicine 46 267-279.

Culbert AA \& Tavare JM 2002 Multiple signalling pathways mediate insulin-stimulated gene expression in 3T3-L1 adipocytes. Biochimica et Biophysica Acta $\mathbf{1 5 7 8} 43-50$.

Cusi K, Maezono K, Osman A, Pendergrass M, Patti ME, Pratipanawatr T, DeFronzo RA, Kahn CR \& Mandarino LJ 2000 Insulin resistance differentially affects the PI 3-kinase- and MAP kinase-mediated signaling in human muscle. Fournal of Clinical Investigation 105 311-320.

Daniel PB, Walker WH \& Habener JF 1998 Cyclic AMP signaling and gene regulation. Annual Revieres in Nutrition $18353-383$.

Duncia JV, Santella JB 3rd, Higley CA, Pitts WJ, Wityak J, Frietze WE, Rankin FW, Sun JH, Earl RA, Tabaka AC et al., 1998 MEK inhibitors: the chemistry and biological activity of U0126, its analogs, and cyclization products. Bioorganic Medicinal and Chemistry Letters 8 2839-2844.

Falvo JV, Parekh BS, Lin CH, Fraenkel E \& Maniatis T 2000 Assembly of a functional beta interferon enhanceosome is dependent on ATF-2-c-jun heterodimer orientation. Molecular and Cellular Biology 20 4814-4825.

Favata MF, Horiuchi KY, Manos EJ, Daulerio AJ, Stradley DA, Feeser WS, Van Dyk DE, Pitts WJ, Earl RA, Hobbs F et al. 1998 Identification of a novel inhibitor of mitogen-activated protein kinase kinase. Fournal of Biological Chemistry 273 18623-18632.

Fry CJ \& Farnham PJ 1999 Context-dependent transcriptional regulation. Fournal of Biological Chemistry 274 29583-29586.

Griffiths MR, Black EJ, Culbert AA, Dickens M, Shaw PE, Gillespie DA \& Tavare JM 1998 Insulin-stimulated expression of c-fos, fral and c-jun accompanies the activation of the activator protein-1 (AP-1) transcriptional complex. Biochemical fournal 335 19-26.

Higuchi R, Krummel B \& Saiki RK 1988 A general method of in vitro preparation and specific mutagenesis of DNA fragments: study of protein and DNA interactions. Nucleic Acids Research $\mathbf{1 6}$ $7351-7367$ 
Horton JD, Goldstein JL \& Brown MS 2002 SREBPs: activators of the complete program of cholesterol and fatty acid synthesis in the liver. Fournal of Clinical Investigation 109 1125-1131.

Hurd TW, Culbert AA, Webster KJ \& Tavare JM 2002 Dual role for mitogen-activated protein kinase (Erk) in insulin-dependent regulation of Fra-1 (fos-related antigen-1) transcription and phosphorylation. Biochemical fournal 368 573-580.

Hutton JC, Peshavaria M, Johnston CF, Ravazzola M \& Orci L 1988 Immunolocalization of betagranin: a chromogranin A-related protein of the pancreatic B-cell. Endocrinology 122 $1014-1020$

Jacoby DB, Zilz ND \& Towle HC 1989 Sequences within the $5^{\prime}$-flanking region of the $\mathrm{S} 14$ gene confer responsiveness to glucose in primary hepatocytes. Fournal of Biological Chemistry $\mathbf{2 6 4}$ 17623-17626.

Kim JJ \& Accili D 2002 Signalling through IGF-I and insulin receptors: where is the specificity? Growth Hormone and IGF Research $1284-90$.

Lenz O, Elliot SJ \& Stetler-Stevenson WG 2000 Matrix metalloproteinases in renal development and disease. Fournal of the American Society of Nephrology 11 574-581.

Leu JI, Crissey MA, Leu JP, Ciliberto G \& Taub R 2001 Interleukin-6-induced STAT3 and AP-1 amplify hepatocyte nuclear factor 1-mediated transactivation of hepatic genes, an adaptive response to liver injury. Molecular and Cellular Biology 21414424 .

Lin F, Kolluri SK, Chen GQ \& Zhang XK 2002 Regulation of retinoic acid-induced inhibition of AP-1 activity by orphan receptor chicken ovalbumin upstream promoter-transcription factor. Fournal of Biological Chemistry 277 21414-21422.

Lucas PC \& Granner DK 1992 Hormone response domains in gene transcription. Annual Reviews in Biochemistry 61 1131-1173.

Lupia E, Elliot SJ, Lenz O, Zheng F, Hattori M, Striker GE \& Striker LJ 1999 IGF-1 decreases collagen degradation in diabetic NOD mesangial cells: implications for diabetic nephropathy. Diabetes 48 1638-1644.

MacKay K, Striker LJ, Elliot S, Pinkert CA, Brinster RL \& Striker GE 1988 Glomerular epithelial, mesangial, and endothelial cell lines from transgenic mice. Kidney International 33 677-684.

McLennan SV, Kelly DJ, Cox AJ, Cao Z, Lyons JG, Yue DK \& Gilbert RE 2002 Decreased matrix degradation in diabetic nephropathy: effects of ACE inhibition on the expression and activities of matrix metalloproteinases. Diabetologia $\mathbf{4 5}$ 268-275.

Maile S, Zimmermann B, Ketteler M \& Merker HJ 2000 The morphology of mesangial cells cultured at high density and in collagen gels. Histology and Histopathology 15 403-414.

Mamounas M, Ross S, Luong CL, Brown E, Coulter K, Carroll G \& Englesberg E 1991 Analysis of the genes involved in the insulin transmembrane mitogenic signal in Chinese hamster ovary cells, CHO-K1, utilizing insulin-independent mutants. PNAS 88 3530-3534.

Martin CC, Oeser JK, Svitek CA, Hunter SI, Hutton JC \& O'Brien RM 2002 Identification and characterization of a human cDNA and gene encoding a ubiquitously expressed glucose-6-phosphatase catalytic subunit-related protein. Fournal of Molecular Endocrinology 29 205-222.

Martin CG, Svitek CA, Oeser JK, Henderson E, Stein R \& O'Brien RM 2003 Upstream stimulatory factor (USF) and neuroD/BETA2 contribute to islet-specific glucose-6-phosphatase catalytic subunit related protein (IGRP) gene expression. Biochemical fournal 371 675-686.

Marzluff WF 1990 Preparation of active nuclei. Methods in Enzymolog $18130-36$.

Mason RM \& Wahab NA 2003 Extracellular matrix metabolism in diabetic nephropathy. Fournal of the American Society of Nephrology 14 $1358-1373$.
Mauer SM 1994 Structural-functional correlations of diabetic nephropathy. Kidney International $45612-622$

Mayr B \& Montminy M 2001 Transcriptional regulation by the phosphorylation-dependent factor GREB. Nature Reviews. Molecular Cell Biology 2 599-609.

Medema RH, Wubbolts R \& Bos JL 1991 Two dominant inhibitory mutants of p21 ras interfere with insulin-induced gene expression. Molecular and Cellular Biology 11 5963-5967.

Miller BS, Shankavaram UT, Horney MJ, Gore AC, Kurtz DT \& Rosenzweig SA 1996 Activation of cJun NH2-terminal kinase/stress-activated protein kinase by insulin. Biochemistry $\mathbf{3 5}$ 8769-8775.

Miyazaki A, Shimura H, Endo T, Haraguchi K \& Onaya T 1999 Tumor necrosis factor-alpha and interferon-gamma suppress both gene expression and deoxyribonucleic acid-binding of TTF-2 in FRTL-5 cells. Endocrinology $1404214-4220$.

Mohn KL, Laz TM, Melby AE \& Taub R 1990 Immediate-early gene expression differs between regenerating liver, insulin-stimulated H-35 cells, and mitogen-stimulated Balb/c 3T3 cells. Liver-specific induction patterns of gene 33, phosphoenolpyruvate carboxykinase, and the jun, fos, and egr families. Fournal of Biological Chemistry $26521914-21921$.

Montminy M 1997 Transcriptional regulation by cyclic AMP. Annual Reviewes in Biochemistry 66 807-822.

Nagase H \& Woessner JF Jr 1999 Matrix metalloproteinases. Fournal of Biological Chemistry 274 21491-21494.

Nakamura T, Fukui M, Ebihara I, Osada S, Tomino Y \& Koide H 1994 Abnormal gene expression of matrix metalloproteinases and their inhibitor in glomeruli from diabetic rats. Renal Physiology and Biochemistry 17 316-325.

O'Brien RM \& Granner DK 1996 Regulation of gene expression by insulin. Physiological Reviews 76 1109-1161.

O'Brien RM \& Granner DK 2004 Gene regulation. In Diabetes Mellitus. A Fundamental and Clinical Text, pp. Eds D LeRoith, SI Taylor \& JM Olefsky. Philadelphia: Lippincott-Raven.

O'Brien RM, Noisin EL, Suwanichkul A, Yamasaki T, Lucas PC, Wang JC, Powell DR \& Granner DK 1995a Hepatic nuclear factor 3- and hormone-regulated expression of the phosphoenolpyruvate carboxykinase and insulin-like growth factor-binding protein 1 genes. Molecular and Cellular Biology 15 $1747-1758$

O'Brien RM, Printz RL, Halmi N, Tiesinga JJ \& Granner DK $1995 b$ Structural and functional analysis of the human phosphoenolpyruvate carboxykinase gene promoter. Biochimica et Biophysica Acta $1264284-288$.

O'Brien RM, Streeper RS, Ayala JE, Stadelmaier BT \& Hornbuckle LA 2001 Insulin-regulated gene expression. Biochemical Society Transactions 29 552-558.

Oemar BS, Foellmer HG, Hodgdon-Anandant L \& Rosenzweig SA 1991 Regulation of insulin-like growth factor I receptors in diabetic mesangial cells. Fournal of Biological Chemistry 266 2369-2373.

Oikawa T \& Yamada T 2003 Molecular biology of the Ets family of transcription factors. Gene 303 11-34.

Ortiz L, Zannini M, Di Lauro R \& Santisteban P 1997 Transcriptional control of the forkhead thyroid transcription factor TTF-2 by thyrotropin, insulin, and insulin-like growth factor I. Fournal of Biological Chemistry 272 23334-23339.

Osterby R 1996 Lessons from kidney biopsies. Diabetes/Metabolism Reviews 12 151-174.

Quandt K, Frech K, Karas H, Wingender E \& Werner T 1995 MatInd and MatInspector: new fast and versatile tools for detection of consensus matches in nucleotide sequence data. Nucleic Acids Research 23 4878-4884.

Reaven GM 1997 The kidney: an unwilling accomplice in syndrome X. American Fournal of Kidney Disease 30 928-931. 
Reynolds JJ \& Meikle MC 1997 The functional balance of metalloproteinases and inhibitors in tissue degradation: relevance to oral pathologies. Fournal of the Royal College of Surgeons of Edinburgh 42 154-160.

Robey RB, Ma J \& Santos AV 1999 Regulation of mesangial cell hexokinase activity by PKC and the classic MAPK pathway. American Fournal of Physiology 277 F742-F749.

Roesler WJ \& Park EA 1998 Hormone response units: one plus one equals more than two. Molecular and Cellular Biochemistry 178 1-8.

Rutter GA, White MR \& Tavare JM 1995 Involvement of MAP kinase in insulin signalling revealed by non-invasive imaging of luciferase gene expression in single living cells (published erratum in Current Biology 19955 1072). Current Biology 5 890-899.

Sambrook J, Fritsch, EF \& Maniatis EF 1989 Molecular Cloning: A Laboratory Manual. Plainview, NY: Cold Spring Harbor Laboratory Press.

Samson SL \& Wong NC 2002 Role of Spl in insulin regulation of gene expression. Fournal of Molecular Endocrinology 29 265-279.

Shaulian E \& Karin M 2002 AP-1 as a regulator of cell life and death. Nature Cell Biology 4 E131-E136.

Sheets EE, Tsibris JC, Cook NI, Virgin SD, DeMay RM \& Spellacy WN 1985 In vitro binding of insulin and epidermal growth factor to human endometrium and endocervix. American fournal of Obstetrics and Gynecology 153 60-65.

Sheetz MJ \& King GL 2002 Molecular understanding of hyperglycemia's adverse effects for diabetic complications. Fournal of the American Medical Association 288 2579-2588.

Shimano H 2002 Sterol regulatory element-binding protein family as global regulators of lipid synthetic genes in energy metabolism. Vitamins and Hormones 65 167-194.

Siddle K, Urso B, Niesler CA, Cope DL, Molina L, Surinya KH \& Soos MA 2001 Specificity in ligand binding and intracellular signalling by insulin and insulin-like growth factor receptors. Biochemical Society Transactions 29 513-525.

Sivak JM \& Fini ME 2002 MMPs in the eye: emerging roles for matrix metalloproteinases in ocular physiology. Progress in Retinal Eye Research 21 1-14.

Streeper RS, Chapman SC, Ayala JE, Svitek CA, Goldman JK, Cave A \& O'Brien RM 1998 A phorbol ester-insensitive AP-1 motif mediates the stimulatory effect of insulin on rat malic enzyme gene transcription. Molecular Endocrinology 12 1778-1791.
Suzuki T, Moriya T, Darnel AD, Takeyama J \& Sasano H 2000 Immunohistochemical distribution of chicken ovalbumin upstream promoter transcription factor II in human tissues. Molecular and Cellular Endocrinology 164 69-75.

Treisman R 1995 Journey to the surface of the cell: Fos regulation and the SRE. EMBO foumal 14 4905-4913.

Vander Kooi BT, Streeper RS, Svitek CA, Oeser JK, Powell DR \& O'Brien RM 2003 The Three insulin response sequences in the glucose-6-phosphatase catalytic subunit gene promoter are functionally distinct. Fournal of Biological Chemistry $\mathbf{2 7 8}$ 11782-11793.

Vihinen P \& Kahari VM 2002 Matrix metalloproteinases in cancer: prognostic markers and therapeutic targets. International fournal of Cancer 99 157-166.

Vincenti MP 2001 The matrix metalloproteinase (MMP) and tissue inhibitor of metalloproteinase (TIMP) genes. Transcriptional and posttranscriptional regulation, signal transduction and cell-type-specific expression. Methods in Molecular Biology 151 121-148.

Visse R \& Nagase H 2003 Matrix metalloproteinases and tissue inhibitors of metalloproteinases: structure, function, and biochemistry. Circulation Research 92 827-839.

Wasylyk B, Hahn SL \& Giovane A 1993 The Ets family of transcription factors (published erratum in European fournal of Biochemistry 1993215 907). European Fournal of Biochemistry 211 7-18.

Waterman MR 1994 Biochemical diversity of cAMP-dependent transcription of steroid hydroxylase genes in the adrenal cortex. fournal of Biological Chemistry $26927783-27786$.

Westermarck J \& Kahari VM 1999 Regulation of matrix metalloproteinase expression in tumor invasion. FASEB fournal 13 781-792.

Wisdom R 1999 AP-1: one switch for many signals. Experimental Cell Research 253 180-185.

Yoon SO, Park SJ, Yun CH \& Chung AS 2003 Roles of matrix metalloproteinases in tumor metastasis and angiogenesis. Fournal of Biochemistry and Molecular Biology 36 128-137.

\section{Received 9 March 2004}

Accepted 6 May 2004 